ELORE (ISSN 1456-3010), vol. 20 - 1/2013.

Julkaisija: Suomen Kansantietouden Tutkijain Seura ry.

[http://www.elore.fi/arkisto/1_13/hamalainen.pdf]

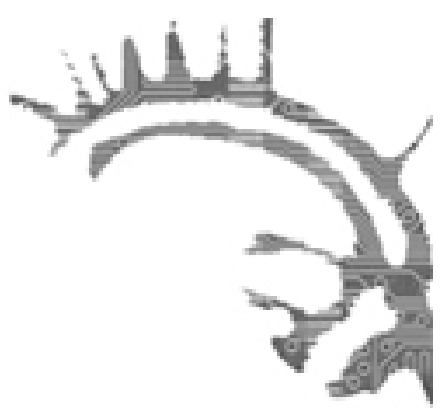

\title{
LECTIO
}

\section{KALEVALAN MODERNI ILME}

\author{
Niina Hämäläinen
}

\section{Lectio praecursoria Turun yliopistossa 17.11.2012}

Tieteellisessä mielessä Kalevala ${ }^{1}$ on paljon tutkittu ja kiistelty teos. Tämän päivän tutkijalle Kalevala saattaa olla raskaskin teos, sillä sen tutkimus- ja tulkintahistoria on pitkä ja tiheä. Vaikka Kalevalaa on määritelty monelta kannalta ja siihen on otettu kantaa siitä saakka, kun se ensimmäistä kertaa ilmestyi vuonna 1835, ei se ole ollut folkloristien parissa suosittu tutkimuskohde.

Turun yliopiston pitkäaikainen folkloristiikan ja uskontotieteen professori Lauri Honko nosti Kalevalan folkloristisen tutkimuksen piiriin 1990-luvulla. Tai pikemminkin hän toi Kalevala-innostuksen takaisin tutkimukseen, josta se oli pitkään ollut poissa. Kalevala oli ollut ongelma, tieteellinen, tulkinnallinen ja poliittinenkin ongelma, johon usein ratkaisuksi kävi vaikeneminen. Kun aloin yhdeksänkymmentäluvun puolivälissä valmistella ensimmäistä opinnäytetyötä, proseminaariesitelmää folkloristiikan perusopintoihin, minun piti kysyä, voiko Kalevalaa tutkia. Kysymys kertoi luonnollisesti nuoren opiskelijan epävarmuudesta ison ja paljon tutkitun aiheen edessä, mutta samalla se kertoi jotain folkloristiikan tutkimushistoriasta ja nykypäivästä ja suhteesta siihen, mistä kaikki alkoi. 
Niina Hämäläinen: Kalevalan moderni ilme

\section{KALEVALAN PERINTÖ}

Suomalainen ja vertaileva kansanrunoudentutkimus, nykyään nimeltään folkloristiikka, sai alkunsa Elias Lönnrotin Kalevalasta. 1800-luvulla kansanrunoudentutkimus keskittyi etupäässä Kalevalaan, jonka nähtiin edustavan jopa paremmin ja aidommin kansanrunoutta kuin runot itse. Kuten kansanrunoudentutkimuksen historian linjoista kirjoittanut Jouko Hautala $(1954,136)$ sanoo, kansanrunoudentutkimusta olisi voitu nimittää yhtä hyvin Kalevalan tutkimukseksi.

Tutkimuksessa löytyi myös runsaasti ristiriitaisia sointuja. Kalevala muodostui monimutkaiseksi haasteeksi, joka ei sopinutkaan uuteen kansanrunoudentutkimuksen metodiin. Julius Krohnin kehittämässä, sittemmin hänen poikansa Kaarle Krohnin jatkamassa niin kutsutussa maantieteellis-historiallisessa menetelmässä tutkittiin kansanrunojen kulkeutumista ja muuntumista ja pyrittiin jäljittämään yhden runon ensimmäinen esitys, runon alkujuuri. Katsottiin, että itse asiassa Kalevalan taakse peittyi koko vanha runokulttuuri, johon kansanrunoudentutkimus juuri olisi suunnattava. Julius Krohn myös erotti kuuluisalla lausahduksellaan Kalevalan pitkäksi aikaa ulos tutkimuksen piiristä. Hänen mielestään "painettu Kalevala, vaikka se on niin taitavasti kokoonpantu, taikka oikeastaan juuri sentähden kun se on niin taitavasti kokoonpantu, ei ollenkaan sovi tieteellisten tutkimusten perustaksi" (sit. Hautala 1954, 191).

Vähitellen Kalevala sivuutettiin ja sitä tutkittiin ja tulkittiin etupäässä estetiikan ja kirjallisuuden puolella. Kirjallisuudentutkimus onkin tuottanut merkittäviä tutkimuksia Lönnrotin eepoksesta. Väinö Kaukosen varhaiset, mittavat säetutkimukset Vanhan ja Uuden Kalevalan kansanrunoaineksista (1939, 1945, 1965) sekä Pertti Karkaman aatehistoriallinen teos Kansakunnan asialla. Elias Lönnrot ja ajan aatteet (2001) ovat muun muassa luoneet linjaa siihen, miten Kalevalaa olisi hedelmällistä tutkia.

\section{Kalevalan AItous}

Puhe Kalevalasta on suuressa märin ollut keskustelua sen autenttisuudesta, joka alkoi heti Kalevalan ilmestyttyä; johon Lönnrot itse osallistui; joka on määritellyt folkloristiikan linjoja ja johon yhä uudestaan palataan. Niin palaan minäkin. Toisaalta autenttisuuskeskustelu on myös harhaanjohtavaa keskustelun osapuolille, sillä se saattaa estää tutkimasta itse Kalevalaa. Tarkoitan tällä sitä, ettei Kalevalaan uskalleta välttämättä tarttua, koska on otettava kantaa sen aitouteen - ja taustalla vaivaa ajatus siitä, ettei eepos ole autenttinen eikä sen vuoksi tutkimuksen arvoinen.

On perusteltua ottaa askel eteenpäin ja unohtaa hetkeksi kysymys eepoksen aitoudesta. Siteeraan Helsingin yliopiston folkloristiikan lehtoria, dosentti Pertti Anttosta (2004, 382): "Kun tutkimuksellinen kiinnostus kohdistetaan kysymykseen siitä, minkälainen Lönnrotin eeposperformanssi on suorituksena ja mitä hän sillä pyrki saamaan aikaan, lähtökohdaksi ei voi ottaa Kalevalan epäaitoutta”.

Tutkimuksessani lyyrisen kansanrunon tekstualisoinnista Kalevalassa Lönnrotin toimitustyötä on tarkasteltu tekstualisaation ja artikulaation näkökulmasta. Tällä tavalla 
Kalevalaa on arvioitu osana 1800-luvun yhteiskuntaa ja sen keskusteluja. Tutkimusmielenkiintoni on kohdistunut Lönnrotin toimituksellisiin ja ideologisiin käytäntöihin toimittaa suullisen perinteen kaltainen eepos. Tällöin merkityksellisiä ovat hierarkkiset merkitykset ja erot suullisen kulttuurin ja sitä representoivan toimittajan ja tämän lukijakunnan välillä. Tekstualisoinnin näkökulmasta Lönnrotin Kalevala on kansanrunojen pohjalta luotu representaatio suullisen runokulttuurin viesteistä, tavoista ja kielestä. Sitä on myös perusteltua tarkastella tämän representaation ja kontekstin puitteissa.

Tässä tutkimuksessa en ole varsinaisesti kysynyt Kalevalalta, vaan kohdistanut pohdintani Elias Lönnrotille. Lönnrot itse olisi saattanut vastata: "Katso, mitä Kalevala tästä sanoo." Olen sivunnut Lönnrotin vastauksen ja kysynyt yhä uudestaan: "Mitä sinä, Elias Lönnrot, itse halusit sanoa?” Koko tutkimusongelmani on kiinnittynyt Lönnrotiin ja tämän päämääriin eepoksen suhteen. Kyse ei pelkästään ole Lönnrotin omista toimituksellisista ja ideologisista tavoitteista, vaan laajemmin siitä kulttuurisesta ja yhteiskunnallisesta ilmapiiristä, kontekstista, jossa Lönnrot eli, työskenteli ja keskusteli. Tältä osin viittaan kirjallisuudentutkija Pertti Karkamaan (2001), jonka mukaan Kalevalaa ei voida tutkia ottamatta kantaa eepoksen valmistumista ympäröivään aikakauteen ja siinä ilmeneviin keskusteluihin.

\section{LÖNNROTIN TEKSTUALISAATIO JA ARTIKULAATIO}

Palataan kuitenkin vielä kysymykseen aitoudesta. Jonkin asian, ilmiön tai olennon (kohteen) aitous on aina määrittelyn varaista. Määrittelyllä arvioidaan myös sitä, mikä ei ole aitoa. Artikulaatiossa toisistaan erilliset asiat tai ilmiöt nivelletään yhdeksi, ikään kuin aidoksi esitykseksi tai käytännöksi. Kalevala yhdisti Suomen kansaa, loi kuvitelman yhteisestä menneestä ja yhteisestä tarinasta. Näennäisesti Kalevala häivytti myös eri ihmisryhmien ja monikerroksisten kansanrunoaineksien välisiä ajallisia, paikallisia ja kulttuurisia eroja.

Lönnrotin Kalevala ja kysymys sen aitoudesta, siitä, missä määrin se vastaa suullisesti välittyneitä kansanrunoja ja laajempaa runokulttuuria, on kytketty tutkimuksessani artikulaation käsitteeseen. Olen runoaineiston empiirisen ja kontekstuaalisen luennan avulla osoittanut, että Lönnrotin kansanrunojen tekstualisointi Kalevalan kehyksessä pyrki täydentämään lukijoiden ymmärrystä, paikkaamaan aukkoja ja tekemään vaikeaselkoisesta, kalevalamitalla kirjoitetusta eepostekstistä luettavampaa. Samalla toimitustyö loi välimatkaa ja syvensi eroa kansanrunojen ja Kalevalan välille, runokulttuurin ja kirjallisen kulttuurin välille, rahvaan ja sivistyneistön välille. Kalevala ei representoinutkaan ainoastaan suullisen kulttuurin merkityksiä ja viestejä, vaan ennen kaikkea modernin, 1800-luvun yhteiskunnan ajatuksia.

Vaikka erot syvenivät, Lönnrot pyrki myös kaventamaan niitä. Yksi kaventamisen keinoista oli toistuva puhe Kalevalan aitoudesta, sen kansanomaisuudesta ja suullisen kaltaisesta esityksestä sekä Lönnrotin oman roolin vähäpätöisyydestä eepoksen kokoonpanossa. Tavallisesti Lönnrot allekirjoitti tai pisti vähintään nimikirjaimensa eri Kalevala-versioiden esipuheiden jälkeen. Kuitenkaan Kalevalan kansilehdillä ei näy 
Lönnrotin nimeä. Useimmiten Lönnrot vetosi eepoksen aitoudessa ja runojärjestyksen oikeellisuudessa epämääräiseen laulajajoukkoon, Kalevala-laulajiin, kansaan. Siteeraan Elias Lönnrotia:

Siinä olemme seuranneet, mitä vanhan väen tarinoimalla olemme Väinämöisen toimista kuulleet ja keralla noudattaneet - - Paikoin on sihen pitänyt täytteeksi omiaki sanoja panna, ei kuitenkaan sillä tavalla, että olisi itse asian perustuksesta poikettu, joka sekä tarinoimalla että laulamalla, kansalta toimitettiin.

(Borenius \& Krohn 1892, 5.)

Aitouskysymys on siis monella tapaa keskeinen tutkittaessa Kalevalaa ja Elias Lönnrotia, ja se määrittää edelleen suuressa määrin myös tieteellistä puhetta Kalevalasta.

Kuitenkin kun Kalevalaa tarkastellaan tekstualisaation näkökulmasta siinä mielessä, miten Lönnrot toimitti, tulkitsi ja uudelleen kontekstualisoi suullisesti elänyttä perinnettä 1800-luvun porvarilliselle lukijakunnalle, kysymys eepoksen aitoudesta muotoillaan toisin. Keskeistä on selvittää, millä keinoilla Elias Lönnrot muokkasi ja nivelsi suullista runoaineistoa kirjalliseen muotoon tavoitellen suullisen kaltaista esitystä sekä minkälaista puhetta Lönnrot piti yllä kokonaisuudestaan. Tällöin eepoksen aitoutta tarkastellaan tietoisena, artikulatiivisena valintakysymyksenä, jonka avulla Lönnrot ohjasi Kalevalan luentaa ja tulkintaa.

\section{MODERNI EEPOS}

Koska folkloristien suhde aineistoon eroaa kirjallisuudentutkijoiden suhteesta aineistoon, on folkloristien löydettävä oma tapansa tutkia Kalevalaa. Aikaisemmin mainitsemani Kaukosen ja Karkaman tutkimukset ovat monin tavoin viitoittaneet myös folkloristiikan piirissä tehtyä Kalevala-tutkimusta.

Kuitenkin vasta Lauri Honko vapautti Kalevalan folkloristien keskuudessa tutkimalla eeposta folkloristiikan ydinalueen, suullisesti välittyvän perinteen kehyksissä. Honko tarkasteli Kalevalaa suullisen runon tuottamisen keinoilla ja määritteli Kalevalan perinneeepokseksi, eepokseksi, joka on kirjallisesti tuotettu mutta jonka aineistojuuret ovat suullisessa kulttuurissa (ks. Honko 1998, 175; 2000, 34).

Suullisen kaltaisuus, jota Honko painotti Kalevalaa luonnehtiessaan, on tutkimuksessani kytketty Lönnrotin ideologisiin tavoitteisiin kansanrunojen tekstualisoinnissa. Tästä näkökulmasta Kalevala ei ole puhtaasti suullista eikä kirjallista perinnettä, vaan monin tavoin ideologisesti tekstualisoitu representaatio kansanrunoista. Siten sitä luonnehtii Pertti Anttosen märittelemänä moderniteetin tuottaminen. Anttonen (2008, 219) katsoo Kalevalan olevan ennen kaikkea moderni eepos, jonka avulla on tuotettu modernia Suomea perinnettä esittelemällä ja tuottamalla.

Tutkimusongelmani kannalta olennaisia ovat olleet ne rajapinnat, joissa suullinen ja kirjallinen kohtaavat, joissa kansanrunoista toimitettu eepos saa lukijansa, ja joissa Elias Lönnrot eli ja toimi. Näistä rajapinnoista löytyy myös Kalevalan moderni ongelma, 
kysymys siitä, millä toimitustavoilla Elias Lönnrot muokkasi suullista perinneaineistoa modernin lukijan odotusten mukaisesti. Tekstualisointi sekä tutkimuksen metodina että tutkimuksen kohteena on tuottanut tuoretta tietoa kansanrunojen toimittamistavoista, Lönnrotin valinnoista ja poisjätöistä. Sen avulla on myös avattu sitä, miten Lönnrot tulkitsi oman aikansa käsityksiä perheestä, äidin roolista ja tunteista Kalevalan kontekstissa.

\section{KALEVALA JA NYKYTUTKIMUS}

Lauri Honko vapautti eräässä artikkelissaan Elias Lönnrotin seuraavilla sanoilla:

On aika vapauttaa Elias Lönnrot ja samalla itsemme romanttisen eeposteorian ikeestä. Antakaamme Lönnrotin laulaa vapaasti suurta kertomusta aineksia perinteestä ammentaen kuten suullisen perinteen laulajat ja kansanrunoeeposten työstäjät ovat tehneet Homeroksen ajoista asti.

(Honko 2000, 36.)

Lopetan lektioni Lauri Hongon sanoja mukaillen ja uudelleen muovaten: on aika vapauttaa tutkijat ja uusi sukupolvi tutkimaan Kalevalaa, kyseenalaistamaan sen merkityksiä ja tulkintoja, epäilemään sen yhtenäisyyden voimaa ja irtautumaan eepoksen aitouden ongelmasta.

HÄMÄLÄINEN, NIINA 2012: Yhteinen perhe, jaetut tunteet. Lyyrisen kansanrunon tekstualisoinnin ja artikuloinnin tapoja Kalevalassa. Annales Universitas Turkuensis, Scripta lingua fennica edita, SER. C, TOM. 349. Turku: Turun yliopisto.

\section{ViITTEeT}

1 Tutkimuksessani Kalevala on jätetty kursivoimatta. Viittaan tällä Lauri Hongon (2000) käytäntöön ja ajatukseen Kalevalasta yhä uudestaan muotoutuvana, suullisen kaltaisena eepoksena, jolla ei ole yhtä, kiinteää muotoa. Honko kutsuukin Lönnrotin eepostyöskentelyä Kalevala-prosessiksi. Vaikka en lähestykään Kalevalaa varsinaisesti suullisen kaltaisena esityksenä, katson Hongon tavoin Lönnrotin tekstualisointityön olleen luonteeltaan yhä uudelleen muotoutuvaa. Ks. Hämäläinen 2012, 39-40.

\section{KirJallisuUs:}

ANTTONEN, PERTTI 2004: Kalevala etnopoeettisesta näkökulmasta. - Siikala, Anna-Leena, Harvilahti, Lauri \& Timonen, Senni (toim.), Kalevala ja lauletturuno. Helsinki: SKS. 
Niina Hämäläinen: Kalevalan moderni ilme

ANTTONEN, PERTTI 2008: Kalevala ja kansalliseepoksen politiikka. - Piela, Ulla, Knuuttila, Seppo \& Laaksonen, Pekka (toim.), Kalevalan kulttuuribistoria. Helsinki: SKS.

BORENIUS, AKSEL \& KROHN, JULIUS 1892: Elias Lönnrot. Kalevalan esityöt II. Runokokous Väinämöisestä. Helsinki: SKS.

HAUTALA, JOUKO 1954: Suomalainen kansanrunoudentutkimus. Helsinki: SKS.

HONKO, LAURI 1998: Textualising the Siri Epic. Helsinki: Academia Scientiarum Fennica.

HONKO, LAURI 2000: Kalevalan viisi esitystä. - Roininen, Niina (toim.), Viimeinen Väinämöinen. Näkökulmia kansalliseepokseen. Turku: Kirja-Aurora.

KARKAMA, PERTTI 2001: Kansakunnan asialla. Elias Lönnrot ja ajan aatteet. Helsinki: SKS.

KAUKONEN, VÄINÖ 1939: Vanhan Kalevalan kokoonpano I. Helsinki: SKS.

KAUKONEN, VÄINÖ 1945: Vanhan Kalevalan kokoonpano II. Helsinki: SKS.

KAUKONEN, VÄINÖ 1956: Elias Lönnrotin Kalevalan toinen painos. Helsinki: SKS.

LÖNNROT, ELIAS [2005] 1862: Kalevala. Lyhennetty laitos. Helsinki.

Filosofian tohtori Niina Hämäläinen on folkloristiikan tutkija. 